\title{
Differences in Academic Achievement in Terms of Adjustment and Regional Origin of Students
}

\author{
Danny Sanjaya Arfensia*, B. Primandini Yunanda Harumi, Muhammad Hanifa Khairurahman, Widya Aulia Noorsasi \\ Faculty of Psychology \\ Universitas Airlangga \\ Surabaya, Indonesia \\ *dannysanjaya@staf.unair.ac.id, b.primandini.yunanda.harumi-2017@psikologi.unair.ac.id, muhammad.hanifa.khairurahman- \\ 2017@psikologi.unair.ac.id, widya.aulia.noorsasi-2017@psikologi.unair.ac.id
}

\begin{abstract}
This study aims to determine whether there are differences in academic achievement of students who come from Surabaya with students who come from outside Surabaya when viewed from the adjustment of the student. This study was conducted on 51 subjects. The measuring instrument used is a self-adjustment questionnaire developed by Semaraputri based on Schneiders theory of $\mathbf{3 0}$ items with alpha cronbach reliability of 0.843. The statistical analysis used is two way Anova. The significance of regional origin variable is 0.932 , meaning the regional origin variable cannot distinguish student academic achievement. The significance of self-adjustment variable is 0.575, meaning that self-adjustment variable cannot distinguish student academic achievement. The significance of the interaction of both variable is $\mathbf{0 . 2 5 6}$, meaning there is no correlation between both variables to student academic achievement.
\end{abstract}

Keywords—self-adjustment, academic achievement, undergraduate students

\section{INTRODUCTION}

In the education system in Indonesia, tertiary education is an important part. The implementation of higher education is one of the government's efforts to fulfill the rights that should be obtained by every citizen. Higher education itself based on Article 2 of Government Regulation Number 60 aims for students to become members of society who have academic and / or professional abilities who can apply, develop and / or create scientific technology and / or arts. Based on the same source, the second objective is to develop and disseminate science, technology and / or arts and seek to use it to improve people's lives and enrich national culture [1].

Citizens who wish to become learners from the educational process in a university are given the widest possible opportunity to be able to choose the path they will use to graduate and be elected. Based on the Regulation of the Minister of Research, Technology and Higher Education Number 1262016 which discusses the Acceptance of New Students for Undergraduate Programs at State Universities, there are a number of patterns of new student admissions that are given. First, the SNMPTN path, which is a selection based on the results of tracking the academic achievements of prospective students. Second, SBMPTN, which is a selection based on the results of a written exam using the print or computer method, or a combination of the results of a written exam and a skills test for prospective students. Third, independent selection, which is a selection that is regulated and determined by each State University [2].

Airlangga University is one of the best public universities in East Java. Airlangga University is ranked in the 7th largest campus in Indonesia according to the Ministry of Research, Technology and Education (2017). In 2018, Airlangga University prepared 5250 seats for the undergraduate level, $30 \%$ for the SNMPTN pathway, $40 \%$ for the SBMPTN pathway, and 30\% for the independent pathway (Masruroh, 2018). Considering the university rankings and the large number of seats available, it is not surprising that many students are interested in applying to UNAIR, both from inside and outside East Java and even those from outside Java. This can be seen from the data described by the Rector of Universitas Airlangga, Nasih that 1,972 students were admitted through the SBMPTN route, with details of which are 1,502 from East Java, 98 from DKI Jakarta, and 92 from West Java, and some from Sumatra, Sulawesi, Kalimantan and Papua [3].

The new students who come from various regions certainly have unique and different characters and habits when compared to students who come from other regions. In order to adapt well to the new campus environment, new students are directed to take part in debriefing activities held by the university concerned, in this case Airlangga University. Based on the Decree of the Director General of Learning and Student Affairs, Ministry of Research, Technology, and Higher Education of the Republic of Indonesia that each university must carefully plan the provision of new students. This provision is also applied at Airlangga University [2]. The provision of new students is aimed at accelerating students' adjustment to the new campus environment. Preparation in order to accelerate adjustment in the university environment is a process that must be carried out by all new university students, including the new Airlangga University students. 
During the adjustment process, problems are often found which then have an impact on student academic achievement.

Tinto states that the first year of lecture is a critical period because this period becomes a time for students to lay foundations which will then affect their academic achievement [4]. In higher education, students are required to have high academic abilities with academic responsibilities that must be met. The high academic responsibility can be seen from the results obtained by students in the form of achievement. Setiawan said that academic achievement can show a person's achievement and success in achieving goals in accordance with his efforts in the academic field [5]. To complete academic dependencies, students must know what forms of responsibility are in the academic field and how to solve these dependencies. Some examples of student academic dependents include attending lectures, completing assignments, and being involved in various activities on campus. In fact, there are still many students who do not plan, monitor, and evaluate their learning activities [6]. This makes them tend to procrastinate doing assignments, do assignments carelessly, collect assignments not according to the time they should, use the overnight speed learning system in the face of exams, and often arrive late in lectures [6]. This was supported by interviews with several new students class of 2017 who are studying at UNAIR. Some of them complained about the difficulty in managing class schedules as a cause of their decreased academic achievement. This affects the students' low academic achievement [6]. Students should not behave like that, because students are responsible for completing activities requested by the faculty in lectures in order to get an understanding of the subject given [7], so that they can have better academic achievement. Based on the description above, the authors are interested in examining the differences in academic achievement in terms of the adjustment of students from Surabaya with students from outside Surabaya.

\section{MethodS}

\section{A. Academic Achievement}

Bloom explains academic achievement as a student learning process that results in changes in knowledge, understanding, synthesis, analytical power, application, and evaluation [6]. Depending on the lesson, academic achievement can be seen from the assignment score, final grade, or GPA [8]. There are nine variables that can affect educational outcomes, namely students' abilities in the form of achievement, motivation, age or developmental stages, quantity of instruction, quality of instruction, classroom climate, living environment, peer groups, and mass media exposure outside of school [7].

Academic achievement is also meaningful as learning achievement in students in the form of an assessment of the efforts given to students from teaching and learning activities in the form of symbols, numbers, letters, and sentences that can explain the results obtained by students within a certain time
[9]. In this study, the measured academic achievement was the student's GPA.

\section{B. Self Adjustment}

Adaptation is the ability within an individual to place himself in accordance with the conditions and environment in order to deal with things that arise in the environment. Adjustment also involves changes in individuals and their environment to achieve satisfaction in dealing with other people and the environment [10]. According to Schneider [11], adjustment is a process that includes changes that are fast, constant, and require an adaptation process to go through it. Self-adjustment is to balance yourself and the environment, so that negative emotions that have nothing to do with the balancing process can be avoided [12]. Individuals with good self-adjustment will be able to provide mature, efficient, satisfying, and healthy responses [13].

According to Atwater [10], there are three aspects regarding self-adjustment, namely: 1) Adjustment to oneself, 2) The need to relate to other people, and 3) There are changes in oneself that have an impact on the environment. The adaptation aspect according to Schneider emphasizes how to deal with environmental problems which consists of 7 aspects, namely [11]: 1) Able to manage excessive emotions, 2) Minimizing self-defense mechanisms, 3) Reducing frustration, 4) Having the ability to learn, 5) Think rationally and be able to direct themselves, 6) Can learn from the past to improve conditions, 7) Able to think realistically and objectively.

The subjects of this study were undergraduate students of the Faculty of Psychology, Airlangga University with a population of 809 students. This study uses non-probability sampling where each member of the population does not have the same opportunity to become research subjects [14]. The non-probability sampling that the writer uses is purposive sampling where the writer determines certain criteria in determining the research subject. The criteria are (1) active students of the Faculty of Psychology, Airlangga University, class 2014-2017, (2) The origin of the school is from the city of Surabaya and outside the city of Surabaya. Researchers used Field's rules to determine the sample, where at least 15 subjects each one variable was represented so that the required research sample was at least 45 people [15].

The data collection technique used was a post-test in the form of a questionnaire that was distributed online. The data in this study were in the form of numbers which were then analyzed statistically. Researchers used a post-test in the form of a questionnaire due to the basic assumption that the subject is the person who understands himself the most [16]. Researchers will ask subjects to fill out a questionnaire containing demographic data and questions related to research variables.

The variable $\mathrm{Y}$ is the academic achievement that can be seen through the student's cumulative grade point index. Meanwhile, variable $\mathrm{X}$ is self-adjustment and regional origin. Self-adjustment is measured using a self-adjustment scale 
based on Schneider's self-adjustment theory developed by Semaraputri [17]. The reliability of this scale is known from alpha cronbach of 0.843 with construct validity of $0.263-0.496$ for 30 items. Regional origin is part of the demographic data that is asked at the beginning of the questionnaire.

This study used two-way ANOVA statistical analysis as a test of difference. This statistical test is carried out by comparing the means between groups that have two independent variables. Two-way ANOVA can also find interactions between the two independent variables on the dependent variable [18]

\section{DISCUSSION}

Can be seen in table 1 that: (1) $51 \%$ of the total sample have a GPA of category B. (2) The number of subjects in the two categories of adjustment can be said to be the same. (3) As many as $60.6 \%$ of the subjects came from outside Surabaya.

TABLE I. DESCRIPTIVE DATA OF RESEARCH SubJeCtS

\begin{tabular}{|c|l|l|l|}
\hline & \multicolumn{1}{|c|}{ Information } & Frequency & \multicolumn{1}{c|}{ Percent } \\
\hline \multirow{4}{*}{ GPA } & AB & 17 & 33.3 \\
\cline { 2 - 4 } & B & 26 & 51.0 \\
\cline { 2 - 4 } & BC & 7 & 13.7 \\
\cline { 2 - 4 } & C & 1 & 2.0 \\
\hline \multirow{2}{*}{$\begin{array}{c}\text { Self } \\
\text { Adjustment }\end{array}$} & High & 26 & 51.0 \\
\cline { 2 - 4 } Origin & Low & 25 & 49.0 \\
\cline { 2 - 4 } & Surabaya & 15 & 29.4 \\
\cline { 2 - 4 } & Outside Surabaya & 36 & 70.6 \\
\hline
\end{tabular}

Table 2 contains descriptive data for the variables to be analyzed. The number of subjects was 51 people. The GPA variable has a mean of 3.289 and a standard deviation of 0.353 . The self-adjustment variable has a mean of 1.49 and a standard deviation of 0.505 . The regional origin variable has a mean of 1.171 and a standard deviation of 0.0460 .

TABLE II. DESCRIPTIVE DATA OF VARIABLE

\begin{tabular}{|c|l|l|l|l|l|}
\hline & \multicolumn{1}{|c|}{$\mathbf{N}$} & \multicolumn{1}{|c|}{ Mean } & SD & Minimum & Maximum \\
\hline GPA & 51 & 3.289 & 0.353 & 2.00 & 3.80 \\
\hline $\begin{array}{c}\text { Self } \\
\text { Adjustment }\end{array}$ & 51 & 1.49 & 0.505 & 1 & 2 \\
\hline Origin & 51 & 1.71 & 0.460 & 1 & 2 \\
\hline
\end{tabular}

Subjects from Surabaya and included in the high selfadjustment category had an average GPA of 3.404. Subjects who came from Surabaya and were in the low adjustment category had an average GPA of 3.194. Subjects from outside Surabaya and included in the high self-adjustment category had an average GPA of 3.268. Subjects from outside Surabaya and included in the low self-adjustment category had an average GPA of 3,311 (see in table 3).
TABLE III. DESCRIPTIVE DATA OF VARIABLE

\begin{tabular}{|c|c|c|c|c|}
\hline & $\begin{array}{c}\text { Self- } \\
\text { Adjustment }\end{array}$ & Mean & SD & $\mathbf{N}$ \\
\hline \multirow{2}{*}{ Surabaya } & High & 3.404 & 0.237 & 7.000 \\
\hline & Low & 3.194 & 0.279 & 8.000 \\
\hline \multirow{2}{*}{$\begin{array}{c}\text { Outside } \\
\text { Surabaya }\end{array}$} & High & 3.268 & 0.448 & 19.000 \\
\hline & Low & 3.311 & 0.310 & 17.000 \\
\hline
\end{tabular}

The results of the normality test show that the GPA variable has a normal distribution with a significance of more than 0.05 on the two independent variables studied (see in Table 4).

TABLE IV. TESTS OF NORMALITY

\begin{tabular}{|c|l|l|l|l|}
\hline \multirow{2}{*}{ Origin } & \multirow{2}{*}{ Last GPA } & \multicolumn{3}{|c|}{ Kolmogorov-Smirnov } \\
\cline { 3 - 5 } & Surabaya & 0.175 & 15 & 0.200 \\
\cline { 2 - 5 } & $\begin{array}{l}\text { Outside } \\
\text { Surabaya }\end{array}$ & 0.108 & 36 & 0.200 \\
\hline $\begin{array}{c}\text { Self } \\
\text { Adjustment }\end{array}$ & High & 0.139 & 26 & 0.200 \\
\cline { 2 - 5 } & Low & 0.095 & 25 & 0.200 \\
\hline
\end{tabular}

The homogeneity test results showed sig. $0.240>0.05$ so it can be assumed that there are the same or homogeneous variants (see in Table 5).

TABLE V. TEST FOR EQUALITY OF VARIANCES

\begin{tabular}{|c|c|c|c|}
\hline $\boldsymbol{F}$ & $\boldsymbol{d} \boldsymbol{f 1}$ & $\boldsymbol{d} \boldsymbol{2}$ & $\boldsymbol{p}$ \\
\hline 1.452 & 3.000 & 47.000 & 0.240 \\
\hline
\end{tabular}

The results of the Two-Way ANOVA are as follows:

- On the Regional Origin variable (Surabaya and outside Surabaya), sig. 0.932>0.05 so that the variable from regional origin cannot differentiate between student academic achievement.

- In the adjustment variable (high and low). Sig. 0.575> 0.05 so that the self-adjustment variable could not differentiate between students' academic achievement

- Interaction of Regional Origin variables * selfadjustment, sig.0.256>0.05 so that there is no interaction (link) between Regional Origin and subject adjustment to student academic achievement

Thus hypothesis is accepted, namely: there is no difference in academic achievement in terms of adjustment and student origin. In addition, there was also no interaction between regional origins and subject adjustment to student academic achievement. 
TABLE VI. ANOVA - GPA

\begin{tabular}{|c|l|l|l|l|l|c|}
\hline Cases & Sum of Squares & df & Mean Square & F & p & $\boldsymbol{\eta}^{\mathbf{2}}$ \\
\hline Origin & $9.482 \mathrm{e}-4$ & 1.000 & $9.482 \mathrm{e}-4$ & 0.007 & 0.932 & 0.000 \\
\hline Self Adjustment & 0.074 & 1.000 & 0.074 & 0.575 & 0.452 & 0.012 \\
\hline Origin * Self Adjustment & 0.170 & 1.000 & 0.170 & 1.323 & 0.256 & 0.027 \\
\hline Residual & 6.031 & 47.000 & 0.128 & & & \\
\hline
\end{tabular}

Based on table 6 the results of research conducted and analysis using Two-Way Anova shows the significance level of differences in regional origins on student academic achievement of $0.932>0.05$ which indicates that there is no difference in academic achievement in terms of the region of origin. There are several other factors that can affect student academic achievement. According to Jimerson, Egeland, and Teo [19], parenting style and parental involvement are one of the things that can affect academic achievement. Good parenting for students and positive involvement in children's education is associated with the attention and support to children who continue their education, so that with the condition that the child lives with or does not live with parents, attention and support can direct students to target- targets to be achieved in college.

The results also show that the level of significance of differences in self-adjustment to student academic achievement is $0.575>0.05$, which indicates that the adjustment variable cannot distinguish student academic achievement. In addition to adjustment, there are individual psychological conditions that can affect academic achievement. According to Djamarah [20], psychological conditions are related to the learning process that students go through. Psychological conditions are related to intelligence, motivation, interests, and individual intelligence, so that students who have good psychological conditions, the learning process can run optimally and produce good achievements.

The interaction between adjustment and regional origin on academic achievement shows $0.256>0.05$ which indicates that there is no interaction between adjustment and regional origin on student academic achievement. According to Yuniah [21], there are other factors that can affect academic achievement, namely having friends and environmental factors. Friends are considered to be able to significantly influence academic achievement. Friends can be a channel for individual feelings when faced with a problem, a place to share deep feelings, and exchange ideas. In addition, the environment in which the subject lives also affect student academic achievement. Watsy explains that environmental factors in general can provide a stimulus to the subject's condition, both physically, psychologically, and socio-culturally.

\section{CONCLUSIONS}

From the results of this study, the researcher obtained a conclusion that students who came from different regions did not have any differences in terms of academic achievement. The high and low adjustment abilities of students during the interaction process in the university environment are also not sufficient to show differences in aspects of academic achievement of these students. The ability to adapt themselves and their origin together does not have an interactional effect on academic achievement.

The suggestion that the author can give based on the results of this study is that there is a need for further research on other factors that can affect academic achievement. The factors that need to be carried out further research are environmental factors such as parenting styles, parental involvement, and motivation from close friends. Internal psychological factors that need to be investigated further are intelligence, motivation, and interest of the student concerned. Considering the results of this study as well, the researcher hopes that students who are studying in tertiary institutions will not be too concerned about matters such as regional origin and poor self-adjustment abilities, when experiencing a decline in academic achievement. Students must be better able to recognize their potential and interest in academic learning. The surrounding environment, such as friends and parents, must also be able to contribute to student academic achievement, by being more directly involved in the learning process or in motivational matters.

\section{REFERENCES}

[1] Peraturan Pemerintah Republik Indonesia, "NOMOR 60 TAHUN 1999," Tentang Pendidik. Tinggi, 1999.

[2] P.T. Peraturan Menteri Riset, Teknologi, Nomor 126 Tahun 2016 , Tentang Penerimaan Mahasiswa Baru PTN. 2016.

[3] D. Sukma, "UNAIR Terima 1.830 Mahasiswa Baru Jalur SBMPTN," UNAIRNews, 2017.

[4] V. Tinto, Leaving college: Rethinking the causes and cures of student attrition. ERIC, 1987.

[5] Setiawan, "Meraih Nilai Akademik Mahasiswa," 2006.

[6] S.S. Fasikhah and S. Fatimah, "Self-regulated learning (SRL) dalam meningkatkan prestasi akademik pada mahasiswa," J. Ilm. Psikol. Terap., vol. 1, no. 1, pp. 145-155, 2013.

[7] J.K. Rugutt and C.C. Chemosit, "A Study of Factors that Influence College Academic Achievement: A Structural Equation Modeling Approach.," J. Educ. Res. Policy Stud., vol. 5, no. 1, pp. 66-90, 2005.

[8] J.L. Price, “An Analysis of Self-Regulated Learning Strategies, Academic Performance, and Satisfaction among Recent Online High School Graduates," 2017.

[9] I. Alawiyah, "Efektivitas Pembelajaran Ekonomi dengan Multimedia terhadap Prestasi Belajar Siswa Kelas X Program Rintisan Sekolah Bertaraf Internasional," 2012.

[10] E. Atwater, Psychology of adjustment: Personal growth in a changing world. Prentice Hall, 1983

[11] A.A. Schneiders, "Personal adjustment and mental health.," 1955 
[12] K. Kartono, Psikologi Perkembangan. Jakarta: Jakarta: Rineka Cipta, 2002.

[13] M. Ali and M. Asrori, "Psikologi Remaja, Jakarta: PT," Bumi Akasara, 2010.

[14] S. Siregar, "Metode penelitian kuantitatif." Jakarta: kencana, 2013.

[15] A.P. Field, Discovering statistics using SPSS for Windows: Advanced techniques for the beginner. Sage, 2009.

[16] S. Azwar, "Dasar-dasar Psikometri (Edisi Kedua)," Yogyakarta: Pustaka Belajar, 2012.

[17] S. Semaraputri and I.M. Rustika, "Peran problem focused coping dan konsep diri terhadap penyesuaian diri pada remaja akhir yang menjadi pengurus organisasi kemahasiswaan di fakultas kedokteran universitas udayana," J. Psikol. Udayana, vol. 5, no. 1, pp. 35-47, 2018

[18] L. Statistics, "Two-way anova in spss statistics (cont),[Online],[Cited October 5th, 2018]." 2018.

[19] D.E. Papalia, S.W. Old, and R.D. Feldman, "Human development (psikologi perkembangan)," Jakarta: kencana, 2008.

[20] S.B. Djamarah, "Psikologi belajar," 2002.

[21] Yuniah, "Faktor-faktor yang Berpengaruh Terhadap Prestasi Akademik Mahasiswa TPB IPB dengan Metode CHAD,” 2006. 